\title{
Towards Adoption of Prefabrication in Construction
}

\author{
Vivian W. Y. Tam ${ }^{1}$, C. M. Tam² ${ }^{2}$ S. X. Zeng ${ }^{3}$ and William C. Y. $\mathrm{Ng}^{4}$
}

\begin{abstract}
There is an urgent issue on huge quantities of construction wastage generation in construction.

Lack of the environmental supports from construction stakeholders should not be provided.

The current implementation of prefabrication seems cannot provide satisfactory results to the construction industry. This paper provides a feasibility analysis in adopting prefabrication in construction activities. Advantages, hindrances and future development on prefabrication's applications are provided based on a questionnaire survey. The suitability in adopting prefabrication of various project types is also examined. Furthermore, a financial analysis is also investigated by a local case study. It found that wastage generation can reduce up to $100 \%$ after adopting prefabrication, in which up to 84.7 per cent can be saved on wastage reduction.
\end{abstract}

Keywords: Prefabrication, waste management, environmental management, construction, Hong Kong

\footnotetext{
${ }^{1 *}$ Correspondence Author, Lecturer , Griffith School of Engineering, Gold Coast Campus, Griffith University PMB50 Gold Coast Mail Centre, Qld 9726, Australia. Email: v.tam@griffith.edu.au.

${ }^{2}$ Professor, Department of Building \& Construction, City University of Hong Kong, Hong Kong.

${ }^{3}$ Professor, Antai School of Management, Shanghai Jiaotong University, China.

${ }^{4}$ Graduate, Department of Building \& Construction, City University of Hong Kong, Hong Kong.
} 


\section{Introduction}

Construction waste is considered one of the main factors having impacts to the environment.

Construction waste is defined as the by-product generated and removed from construction, renovation and demolition workplaces or sites of building and civil engineering structure [1].

With the increasing demands in implementing major infrastructure projects, together with many commercial buildings and housing redevelopment programmes, a large amount of construction waste is being produced. Existing works have proposed various waste management approaches. Petts [2] promoted the proactive community involvement in implementing waste management, and suggested consensus building among the public in order to control waste generation and mitigate the waste impacts to the environment. Coffey [3] pointed out that considerable waste reduction can be achieved if waste management is implemented as part of project management functions. He suggested that whilst the choice of the optimum waste handling methods should be determined by considering the cost implications, any practices, which will induce waste reduction, must be encouraged.

The provision for training and education among staff and involving employees’ participation as more effective approaches in implementing waste management [4-5]. However, employees’ participation could only be effective with genuine support from management [4]. In fact, a previous survey reported that waste management has been receiving less attention from 
business senior management in comparing with construction cost and time [5]. The cost for implementing waste management is often given more concern than the possible benefits that the organization can gain from the implementation.

In recent years, construction waste reuse and recycle have been promoted in order to reduce wastes and protect the environment, but the effectiveness of their application has been of limitation largely because the conditions for applying these approaches were not provided [6]. These conditions include proper site location and equipment for waste sorting out, good experience in waste recycling operations, trained supervisors and employees, knowledge of secondary materials markets and knowledge of environmental and safety regulations.

In Hong Kong, the government is promoting the sense of environmental protection, and has been addressed in 1989 white paper, which laid down the framework for a comprehensive 10-year plan to fight against construction waste.

The local government's controls in construction waste include the implementation of Environmental Management System (EMS), Waste Reduction Framework Plan (WRFP) and various environmental related Ordinances. However, the implementation of prefabrication for the major wet-trade construction activities seems to lack to be enforced by the government on 
the building development.

This paper provides a feasibility analysis in the applications of prefabrication in construction activities. The following issues are highlighted:

- Examines waste management in construction;

- Investigates benefits, difficulties and measures in adopting prefabrication;

- Proposes effective prefabrication models for various project types; and

- Explores a financial analysis in adopting prefabrication by a local case study.

\section{Waste Management Strategy}

Waste management in construction activities had been promoted for protecting the environment in line with the recognition that the wastes from construction works contribute significantly to the polluted environment. Construction activity is approximately to generate $20 \%$ to $30 \%$ of all wastes deposited in Australian landfills [7]; $29 \%$ of the solid-waste stream in the USA is construction waste [8]. More than $50 \%$ of the waste deposited in a typical landfill in United Kingdom comes from construction waste [9]. Therefore, uncollected construction solid waste has become a major health hazard $[10,11]$.

Running out of space for waste disposal is happening. Construction industry generates a huge 
quantity of waste everyday and this amount reaches to $40 \%$ of the total waste intake at the landfills areas. Three main landfills areas are used in Hong Kong, namely, South East New Territories (SENT) landfill, North East New Territories (NENT) landfill and West East New Territories (WENT) landfill (see Figure 1). However, those landfill sites are being running out and exhausted in 10 to 15 years [12] (see Tables 1 and 2).

$<$ Figure 1 $>$

$<$ Table $1>$

$<$ Table 2>

The conventional construction method consists of extensive cast-in-situ activities being widely used, is now under criticizing. Huge quantities of unwanted but useful surplus materials are running out of space to dispose, thus conventional method is quite difficult and not effective to control wastage of building materials on construction site. For sustainable development and to conserve landfill capacity, there is an urgent need for the industry to adopt certain new construction methods or technologies, which can reduce waste effectively [13]. Therefore, prefabrication is being widely used in European countries, Japan and Singapore.

\section{The Survey}


Many prefabricated building components had been introduced in Hong Kong construction. The applications of facade and staircase are the most common practices for construction activities, which can effectively reduce the waste generation and improve the environmental performance for the overall site conditions. In order to unveil the advantages, hindrances and further development of the applications of prefabrication on construction site, a questionnaire survey was conducted, which were sent to two hundred parties, including government departments, developers, consultants, main contractors and sub-contractors. Seventy have been completed and returned with a response rate of 35 percent. However, six of the questionnaires were not properly completed and only sixty-four questionnaires were valid for the analysis.

\section{Results and Analysis}

\section{$\underline{\text { Advantages for Adopting Prefabrication }}$}

Many researchers had identified the advantages of applying prefabrication [14-15]. Seven benefits of applying prefabrication are used for conducting the survey: i) frozen design at the early design for better adoption of prefabrication; ii) better supervision on improving the quality of prefabricated products; iii) reduce overall construction costs; iv) shorten construction time; v) environmental performance improved for waste minimization; vi) integrity on the building design and construction; and vii) aesthetic issues on the building. 
The benefits in applying prefabrication are considered as having different levels of significance to construction businesses, and the main focus of the survey is to identify the level of recognition of these beneficial aspects. For each beneficial factors, the respondents were requested to judge the significance level by selecting one of five grades, namely, least significant, fairly significant, significant, very significant and extremely significant. The survey results are summarized in Table 3 and Figure 2.

$<$ Table 3>

$<$ Figure 2>

To examine the relative levels of the significance among these factors on benefits, an alternative approach is used to calculate the average values. According to Table 3 and Figure 2, "better supervision on improving the quality of prefabricated products" ranked as first with average value of 4.09. The respondents claimed that prefabrication of building components can achieve better quality product by having better supervision, as the prefabricated products are tested and inspected before site installation.

"Frozen design at the early stage for better adoption of prefabrication" and "reduce overall construction costs” are ranked as second and third with the average values of 3.91 and 3.63 
respectively. One of the respondents explained that if the standardized design layouts are used at the early stage with similar as the previous projects, the achievement on the performance in cost reduction will be much better. Adopting prefabrication and mass production of building components can reduce construction cost effectively.

The respondents argued that other than the cost can be saved from the early-standardized design layout, time can also be reduced as the prefabrication can increase the productivity and efficiency of building construction, in which this interpretation is in line with the survey's result of ranked as the fourth of the advantages of prefabrication with average value of 3.50 .

\section{Hindrances for Adopting Prefabrication}

Other than the advantages in adopting prefabrication, the disadvantages on the applications of prefabrication will also be investigated. Ten hindrances on applying prefabrication are being adopted for the survey [14-15]: i) inflexible for changes of design; ii) higher initial construction cost; iii) lack of background research information; iv) time consuming in the initial design development; v) lack of consideration for the advantages on adopting conventional construction methods on site; vi) limited site space for placing prefabricated building components; vii) leakage problems will be occurred for the joining of the prefabrication; viii) lack of experiences on the contractors; ix) monotone in aesthetics issues 
for building; and x) lack of demand for prefabricated building components.

Similar as the analysis on the advantages of prefabrication, five significant levels will be responded from least significant to extremely significant. Table 4 and Figure 3 show the responses on the hindrances on applying prefabrication.

$<$ Table 4>

$<$ Figure 3 $>$

From Table 4 and Figure 3, “inflexible for changes of design” is ranked as first on the hindrances of applying prefabrication with average value of 3.62. The respondents argued that consultants and client are reluctant to adopt prefabrication for the previous projects, since the design has not frozen in development stage, which will affect adoption of prefabrication and environmental awareness for various construction parties.

"Higher initial construction cost" is graded fourth with the average value of 3.39. In the discussion, the respondents explained that although the contractor found the initial cost would be higher, it is suggested to minimize the cost by deploying the advance heavy industry to Mainland China, in which some of the Hong Kong contractors had already started to build their prefabricated factories in the China practices. 
Although "leakage problems will be occurred for the joining of the prefabrication" is not found to be the major hindrances on adopting prefabrication with an average value of 2.89 from the survey, the serious of the leakage problems seem cannot be controlled on the current practices in Hong Kong housing construction.

\section{$\underline{\text { Future Development for Prefabrication Applications }}$}

Some recommended future development for an effective and efficient application of prefabrication are suggested [11,14-15]: i) relaxation of the gross floor area (GFA) for environmental design; ii) adopting prefabrication to the future projects by improving environmental awareness; iii) considering construction methods at the early design stage for standardization; iv) putting environment as the first priority on adopting prefabrication; and v) developing construction techniques for prefabrication applications.

The results are summarized as Table 5 and Figure 4.

$<$ Table 5>

$<$ Figure $4>$ 
“Considering construction methods at the early design stage for standardization” is considered as the most effective future development for better adopting prefabrication, in which it achieved the average value of 3.72. In the discussions, the respondents claimed that various construction methods will be dependent on the design layout, thus an early consideration of adopting standardized design should be effective for environmental management and waste minimization on construction processes.

According to Table 5 and Figure 4, it is found that "adopting prefabrication to the future projects by improving environmental awareness” and “developing construction techniques for prefabrication applications” are recommended for future development in the applications of prefabrication, which both ranked as second of the average value of 3.34. Majority of the respondents are agreed that prefabrication can be applied for the future projects; however, the levels in adopting prefabricated building components should be dependent on the natures of the projects. For better promotion on environmental management and waste minimization, training and education should be provided to the construction organization [5].

\section{Suitability of Prefabricated Building System for Various Project Types}

After the measures for better implementation of prefabrication is surveyed on the aforementioned sections, a feasibility study is examining the prefabrication building models 
for various type of building projects. The idea for applying manufacturing technologies to the construction industry had applied for many years. Designers had explored the use of industrialized building techniques and methods as a solution for solving problems in human behaviour. Industrialization in building construction and adoption of prefabrication had been briefly introduced in construction. Industrialization is the aspect of manufacturing process which by using mass production techniques results in an increase in productivity, efficiency and quality of the product.

For collecting the experiences and opinions in adopting prefabrication in the construction site activities, four major types of building projects are considered, namely, general project, public housing, private residential and commercial projects. The data were collected analyzed. In order to understand whether the model will vary according to the project natures, comparison will be made accordingly. Firstly, the model will be presented disregarding the project nature, named as general projects. Afterwards, opinions in relation to project natures, including public housing project, private residential project and commercial project are surveyed.

Six building elements including substructure, drainage and underground services, structural frame, external works, internal works and building services had been asked on the respondents for suggesting various types of construction methods, such as conventional, 
semi-prefabrication, comprehensive prefabrication and volumetric off-site fabrication, in relation to types of projects.

For the sake of clear understanding of the applications of prefabrication in various types of building projects, the model was constructed based on major building elements against the degree of the applications of prefabrication. Six primary elements, namely, substructure, drainage and underground services, structural frame, external works, internal works and building services, including a number of sub-elements of off-site prefabrication had been grouped for analysis [18].

\section{General Project}

The surveyed opinion and recommendation about general projects, which discard the consideration for various types of project, is tabulated as in Table 6 under different categories of building elements.

$<$ Table 6>

According to the data collected in Table 6 on substructure, it found that $100 \%$ and $96.3 \%$ of the respondents suggested using conventional method for construction in foundation and basement respectively. It is quite reasonable that foundation and basement are non-standard 
design and may subject to change in responding to the underground conditions which are difficult to adopting prefabrication and predicted beforehand.

For the drainage and underground services, it is further subdivided into manhole, piping, and plant and equipment. Although there is some of the respondents are suggesting prefabrication method, the majority on $76 \%, 69.2 \%$ and $48.1 \%$ would be suggested adopting conventional method on plant and equipment, piling and manhole respectively. Both drainage and underground services are using standard range of prefabricated elements, which made from concrete, polymer and cast iron; therefore, it is more convenient for using cast in-situ installation on construction activities.

Six sub-elements in structural frame are classified: column, beam, bearing wall, lift shaft, stair, and slab. The majority of the respondents are recommended using conventional construction of $48.1 \%, 42.3 \%, 46.4 \%$ and $20 \%$ on column and beam, bearing wall, lift shaft, and stairs and slab respectively. Although conventional method is recommended by the majority of the respondents, system formwork is also ranked as the second recommended construction method for structural frame for enhancing the performance in terms of productivity and waste reduction; however it should depends on the natures of projects. 
For the elements of external works, conventional method is also highly recommended by the respondents, in which $20.7 \%$ and $66.7 \%$ are suggested for external wall and roof respectively. However, another $51.4 \%$ on external wall's responds are argued that adopting comprehensive prefabrication can be achieved waste minimization in construction, for external facade is the most popular applications for prefabrication in the practices on external walls.

Conventional construction method is still highly recommended for the applications in internal works in terms of plastering, tiling, washroom and kitchen, for $48.3 \%, 48.4 \%, 43.3 \%$ and $40.7 \%$ of respondents are recommended respectively. Some of the respondents are also encouraged the fundamental perception for applying the plastering, tiling, washroom and kitchen offsite in prefabrication that will be worthwhile for economies of scale.

Normally, escalator, lift and distribution ductwork are prefabricated offsite for site installation; however, the majority of the respondents are suggesting conventional construction methods of $76.9 \%, 67.9 \%, 63 \%$ and $59.3 \%$ on plant room, lift, escalator and distribution ductwork construction respectively. Since prefabrication is becoming a norm of distribution ductwork, plant room, escalator and lift, thus conventional construction shall only refer to site installation of the prefabricated product as discussed with the respondents. 
Although the majority of the construction elements, including substructure, drainage and underground services, structural frame, external works, internal works and building services are recommended cast-in-situ, modular prefabrication should also be encouraged in the construction, which should found to be effective and efficient from the experiences of the United Kingdom [19].

\section{$\underline{\text { Public Housing, Private Residential and Commercial Projects }}$}

For the waste generations on construction and demolition are included in a large amount of the total wastes generated, public housing, private residential and commercial projects are the major construction development in the construction, while industrial, school and other projects are not involved in a large values in the waste generation. Therefore, effective model for public housing, private residential and commercial projects should be considered and recommended by the respondents for better constructed on site. Tables 7, 8 and 9 summarized the results on the interviewees' opinion on the model for public housing, private residential and commercial projects respectively.

$<$ Table $7>$

$<$ Table 8>

$<$ Table 9> 
In comparing the recommended construction methods for public housing, private residential and commercial projects in Tables 7, 8 and 9 respectively, it found that the conventional construction methods are nearly $100 \%$ recommended for the foundation and basement construction in substructure for public housing, private residential and commercial projects, which may be the unexpected circumstances on the underground environment on the projects.

Comprehensive prefabricated construction methods are suggested on the developments for pubic housing projects on structural frame of 33.3\%, 50\%, 33.3\%, 50\% and $66.6 \%$ in column, beam, bearing wall, lift shaft and stairs, and slab respectively and envelop of $100 \%$ and $33.3 \%$ in external wall and roof respectively, as the results shown in Table 7; while private residential and commercial projects are only highly recommended for the adoption of conventional construction methods for the un-standardized design layout on those projects.

Although conventional construction methods are still the major adoption in the construction for housing and commercial developments, the building services on commercial projects are recommended for adopting neither semi-prefabrication or comprehensive prefabrication of $40 \%$ and $40 \%, 25 \%$ and $25 \%$, and $16.7 \%$ and $66.6 \%$ for distribution ductwork, plant room, and lift and escalator construction respectively. These results may come from the practices of adopting the similar sized building services for the commercial and office design. 
Although the adoption of the prefabrication still not strongly encouraged by the construction industry from the structured survey, there is a tendency for adopting modular prefabrication for the washroom in public housing and private residential building since it fulfill the key characteristics of prefabrication as discussed by Warszawski [20] like standardization, repetition, adopted in the design stage, mass production and client's requirement. The applications of the above suggested effective prefabrication model for the general projects, public housing, private residential and commercial projects in the construction, will also depend on the education and training for the frontline employees by enhancing their environmental awareness.

Based on the discussions with the interviewees, only five major elements can fulfill the basic prerequisite requirements of the effective prefabrication model in the presents practices of the construction activities: i) steel structural frame; ii) prefabricated external cladding; iii) prefabricated concrete slab; iv) comprehensive prefabricated washroom; and v) dry wall system. Since most of the prefabrication products are load bearing, the development of lightweight prefabrication should be introduced for reduce the cost on materials and transportation is the major tasks in construction. 


\section{Wastage Levels between Conventional and Prefabrication Constructions}

Prefabrication is considered as an effective and efficient procedure for waste minimization.

Prefabrication technique can be applied for all of the construction projects; however, none of the research had done about the effectiveness on implementation of prefabrication to various types of construction projects. In order to explore wastage reduction in adopting prefabrication, thirty construction projects on adopting conventional construction and prefabrication are being measured the levels of waste generation with the details summarized as in Table 10.

$<$ Table 10>

In the survey, there are fourteen conventional construction projects, with twelve private housing projects and the other two are public housing projects. As Table 11 shown that the conventional construction methods are mainly adopted by private housing, while public housing projects are rarely to using the traditional in-situ methods on site activities, only applications on the industrial and school projects. On the other hand, sixteen over thirty of the construction projects are using semi-prefabrication in the site construction activities (see Table 12). Six construction projects are measured from private housing projects, while ten construction projects are measured from public housing projects. Most of the projects adopting semi-prefabrication are residential projects, which involved $75 \%$ of the measured 
semi-prefabrication projects. The others of the semi-prefabrication projects are commercial and office projects; however, industrial, hotel and school projects are rarely adopting prefabricated building components in construction.

$<$ Table 11>

$<$ Table 12>

Although wastage levels may vary from different types or natures of project, the wastage levels are believed affected by the adoption of conventional in-situ and prefabrication construction methods. A structured survey was conducted to measure the wastage level for the different construction methods. The average wastage levels (in per cent) for various construction trades, namely, concreting, rebar fixing, bricklaying, drywall, plastering, screeding and tiling, are measured for the two groups of projects adopting conventional in-situ trades and prefabrication denoted as ' $A$ ' and 'B' as shown in Table 13. After measured the values of (A) and (B), the percentage in waste reduction, (C), is calculated by obtaining the difference between the average wastage level in conventional and prefabrication construction methods (A) and (B) by the ratio of the waste reduction over the average wastage level for the conventional construction method.

$<$ Table 13> 
According to the findings on the average wastage levels for the major construction activities carried out on site as shown in Table 13, it is noted that the most effective waste reduction trade is plastering, which can have $100 \%$ of wastage reduction after adopting prefabrication. It can be explained that plastering can be avoided since the concrete surface of the precast items is smooth and even enough for receiving tile or subsequent finishes. During the interview discussions, the contractors argued that tiling was directly applied to the concrete surface after formwork striking, while receiving painting, only a layer of 1 to $2 \mathrm{~mm}$ thick skim coat is required instead of 15 to $20 \mathrm{~mm}$ plastering.

According to Table 13, the average wastage level of the conventional construction method is much higher than that of prefabrication in the trades of concreting, rebar fixing, plastering and tiling. This result shows that the wastage levels vary with different trades when prefabricated building components are adopted; therefore, the standardized designs of building can reduce the wastage levels effectively.

The private housing projects generate the highest wastage levels especially for steel reinforcement, which may reflect from the non-standardized building structures resulting in different sizes of formwork, reinforcement, and brick / block work that generate higher levels of material wastage. 
Poon et al. [21] addressed the different wastages of materials in the trades of concreting, reinforcement, drywall, plastering, screeding, tile, formwork and masonry for private and public housing projects with the results summarized in Table 14. The table shows that the wastage in formwork, plastering and screeding for private housing projects is much higher than that for public housing projects. For the standardized design in public housing, adoption of prefabrication is more common. Therefore, it can be concluded that prefabrication can minimize construction waste effectively; the magnitude of waste reduction depends on the level of prefabrication.

$<$ Table 14>

Skoyles and Skoyles [22] pointed out a problem that the natural level of material wastage depends on the cost effectiveness of the approaches used to control it. Therefore, the cost of reducing wastage directly relates to the values of material saved; however, this relationship is no longer linear. Higher cost effectiveness can only be achieved at the initial project development stage, and lower cost effectiveness happens at the later stages. Thus, the optimum level of material saved should be identified before projects start. The optimum level should be the small improvement cost in reducing wastage that brings about a large impact on materials saved and increase in profits. It seems to be more effective to reduce the wastage for 
items bearing higher levels of wastage, which have relatively larger room for wastage reduction. This approach is important in determining where attention should be focused to maximize saving from material wastage.

\section{Financial Analysis in Adopting Prefabrication: A Case Study}

After analysis the wastage reduction in adopting prefabrication, a typical project is illustrated to highlight financial behaviour of project. The quantities of materials used in an example of a project are summarized in Table 15.

$<$ Table 15>

Four materials are focused in this project, including concrete, reinforcement, plastering and tiling. The wastage level of this project is twenty per cent [it stated as "original quantity of waste" in Table 15]. As analyzed the wastage reduction after adopting prefabrication in the previous section [it stated as "wastage reduction level” in Table 15], the wastage level reduced significantly [it stated as "new quantity of waste” in Table 15].

From the result, it clearly illustrated that a huge amount of wastage can be reduced after adopting prefabrication. Up to 84.7 per cent can be saved for wastage reduction for four major types of materials. However, prefabrication will only be successful when contractors and 
developers enjoy cost savings. Interviewees suggested that cost was the key factor at this critical moment of economical downturn. Prefabrication will only bring about cost saving when the following issues are addressed: i) fully mechanizing the construction process using heavy plants; ii) turning construction into an assembling industry rather than site production; and iii) use of recycle materials for the prefabricated components. In addition, three main stimulators are needed in adopting prefabrication [11,14,15]:

i) Environmental issues: when more stringent environmental control and regulations are forthcoming, prefabrication is one of the ways out in order to facilitate long-term waste minimization and reduction;

ii) Construction costs: introducing more productive and lean construction methods can reduce the construction cost effectively and reduce the burden encountered by the high initial investment [5];

iii) Government incentives: granting relaxation to the gross floor area for projects employing prefabrication elements (for example, discounting the area occupied by facade units proposed by the Hong Kong government recently) [13] will encourage the use of prefabrication. Moreover, tighter control on workmanship, allowable tolerances, homogeneity, and allowable rework will favour the adoption of prefabrication.

\section{Conclusions}


Waste management have been becoming an important issue in the construction industry. Prefabrication can provide a better solution to the problems in huge waste generation on site activities. Adoption of prefabrication is potential for the construction industry though there still are many problems in the applications on prefabrication. Although there are many hindrances for the prefabrication, supervision can be better to achieve in terms of environment and quality. Long-term construction costs can be reduced even the initial construction cost is higher. For better implementation of prefabrication, early design stage should be considered for including the construction methods at the construction processes. The development of the effective prefabrication models for general project, public housing, private residential and commercial projects should also be demonstrated as another waste minimization trend in the construction industry. The adoption of prefabrication and modular construction should be build up by enhancing the environmental awareness through education and training focused by the government. The survey results can give out a positive concept in the applications of prefabrication for the future projects, which should be good news in the construction.

\section{Reference}

1. Cheung C.M. Guidelines for reduction of construction waste on building sites. Faculty of Construct ion and Land Use, Department of Building and Real Estate, The Hong Kong Polytechnic University, 1993. 
2. Petts J. Waste management strategy development: a case study of community involvement and consensus-building in Hampshire. Journal of Environmental Planning and Management 1995;38(4):519-536.

3. Coffey M. Cost-effective systems for solid waste management. Waterlines 1999;17(3):23-24.

4. Lingard H., Gradam P., Smithers G. Employee perceptions of the solid waste management system operating in a large Australian contracting organization: implications for company policy implementation. Journal of Construction Management and Economics 2000;18(4):383-393.

5. Shen L.Y., Tam W.Y.V. Implementation of environmental management in the Hong Kong construction industry. International Journal of Project Management 2002;20(7):535-543.

6. Chun L.P., Domenic E.S., Charles J.K. Strategies for successful construction and demolition waste recycling operations. Journal of Construction management and Economics 1997;15(1):49-58.

7. Craven E.J., Okraglik H.M., Eilenberg I.M. Construction waste and a new design methodology. Sustainable Construction: Proceedings. Of the $1^{\text {st }}$ Conference of CIB TG 16 (ed. C. J. Kilbert), 1994, 89-98.

8. Rogoff M.J., Williams J.F. Approaches to implementing solid waste recycling facilities. Noyes, Park Ridge, NJ, 1994. 
9. Ferguson J., Kermode N., Nash C.L., Sketch W.A.J., Huxford R.P. Managing and minimizing construction waste: a practical guide. Institution of Civil Engineers, London, 1995.

10. Cotton A., Snel M., Ali M. The challenges ahead - solid waste management in the next millennium. Waterlines 1999;17(3):2-5.

11. Poon C.S. Management and Recycling of Demolition Waste in Hong Kong. Proceedings, $2^{\text {nd }}$ International Conference on Solid Waste Management, Taipei, Taiwan, 2000, 433-442.

12. Waste Reduction Framework Plan. Waste reduction framework plan 1998-2007, Environmental Protection Department, Hong Kong government, 1998.

13. Environmental Protection Department. Homepage, available at http://www.info.gov.hk/epd, 2003 [access date: 24 Juen 2003].

14. Ho O.S.T. Construction waste management - a contractor's perspective. The Hong Kong Institute of Builders, 2001, July, 8-11.

15. Ting Y.H. The economic implications of subcontracting practice on building prefabrication. Automation in Construction 1997;6(3):163-174.

16. Finn D.W. Towards industrialized construction. Construction Canada 1992;34(3):25-28.

17. Tatum C.B. Constructability improvement using prefabrication, pre-assembly, and modularization: technical report no. 297. Stanford University, California, USA, 1986.

18. Gibb A.G..F. Off-site fabrication: prefabrication, pre-assembly and modularization. Scotland, Whittles, 1999. 
19. Neale R., Price A., Sher W. Prefabricated modules in construction: a study of current practice in the United Kingdom. London, CIOB, 1993.

20. Warszawski A. Industrialized and automated building systems. London and New York: E \& FN Spon, 1999.

21. Poon C.S., Yu T.W., Ng L.H. A guide for managing and minimizing building and demolition waste, The Hong Kong Polytechnic University. 2001.

22. Skoyles E R., Skoyles J.R. Waste prevention on site, London: Mitchell, 1987. 
Table 1: Landfill void space consumption [13]

\begin{tabular}{|l|c|c|c|}
\hline \multicolumn{4}{|c|}{ Void space consumption (end 2000) } \\
\hline Landfills & Design capacity & Percentage consumption & Remaining capacity \\
\hline SENT & $43.1 \mathrm{Mm}^{3}$ & $34 \%$ & $28.6 \mathrm{Mm}^{3}$ \\
\hline NENT & $35.0 \mathrm{Mm}^{3}$ & $20 \%$ & $28.1 \mathrm{Mm}^{3}$ \\
\hline WENT & $61.9 \mathrm{Mm}^{3}$ & $15 \%$ & $52.8 \mathrm{Mm}^{3}$ \\
\hline $\begin{array}{l}\text { Notes: } \\
\text { South East New Territories - SENT; } \\
\text { North East New Territories - NENT; and } \\
\text { West New Territories - WENT }\end{array}$ \\
\hline
\end{tabular}


Table 2: Landfill life expectancy [13]

\begin{tabular}{|l|c|c|c|}
\hline \multicolumn{3}{|c|}{ Landfill life expectancy } \\
\hline & Optimistic scenario & Pessimistic scenario & Worst scenario \\
\hline Waste growth & Low & High & High \\
\hline $\begin{array}{l}\text { Achieve waste reduction } \\
\text { targets }\end{array}$ & $\checkmark$ & $\mathbf{x}$ & \\
\hline Sufficient public fill outlets & $\checkmark$ & $\checkmark$ & $\mathbf{x}$ \\
\hline SENT & 2012 & 2010 & 2005 \\
\hline NENT & 2016 & 2013 & 2008 \\
\hline WENT & 2018 & 2013 & \\
\hline $\begin{array}{l}\text { Notes: } \\
\text { South East New Territories - SENT; } \\
\text { North East New Territories - NENT; and } \\
\text { West New Territories - WENT }\end{array}$ & & \\
\hline
\end{tabular}


Table 3: Advantages of applying prefabrication

\begin{tabular}{|l|c|c|c|c|c|c|}
\hline $\begin{array}{l}\text { Advantages of } \\
\text { prefabrication }\end{array}$ & $\begin{array}{c}\text { Least } \\
\text { significant }\end{array}$ & $\begin{array}{c}\text { Fairly } \\
\text { significant }\end{array}$ & Significant & $\begin{array}{c}\text { Very } \\
\text { significant }\end{array}$ & $\begin{array}{c}\text { Extremely } \\
\text { significant }\end{array}$ & $\begin{array}{c}\text { Average } \\
\text { value }\end{array}$ \\
\hline $\begin{array}{l}\text { Frozen design at the } \\
\text { early stage }\end{array}$ & $3 \%$ & $3 \%$ & $16 \%$ & $56 \%$ & $22 \%$ & 3.91 \\
\hline Better supervision & $0 \%$ & $3 \%$ & $6 \%$ & $69 \%$ & $22 \%$ & 4.09 \\
\hline $\begin{array}{l}\text { Reduce construction } \\
\text { costs }\end{array}$ & $0 \%$ & $16 \%$ & $22 \%$ & $47 \%$ & $16 \%$ & 3.63 \\
\hline $\begin{array}{l}\text { Shorten construction } \\
\text { time }\end{array}$ & $6 \%$ & $13 \%$ & $22 \%$ & $44 \%$ & $16 \%$ & 3.50 \\
\hline $\begin{array}{l}\text { Improve environmental } \\
\text { performance }\end{array}$ & $16 \%$ & $59 \%$ & $13 \%$ & $13 \%$ & $0 \%$ & 2.22 \\
\hline Integrity of the building & $9 \%$ & $16 \%$ & $16 \%$ & $50 \%$ & $9 \%$ & 3.34 \\
\hline Aesthetic issues & $6 \%$ & $6 \%$ & $31 \%$ & $56 \%$ & $0 \%$ & 3.38 \\
\hline
\end{tabular}


Table 4: Hindrances on applying prefabrication

\begin{tabular}{|l|c|c|c|c|c|c|}
\hline $\begin{array}{l}\text { Hindrances of } \\
\text { prefabrication }\end{array}$ & $\begin{array}{c}\text { Least } \\
\text { significant }\end{array}$ & $\begin{array}{c}\text { Fairly } \\
\text { significant }\end{array}$ & Significant & $\begin{array}{c}\text { Very } \\
\text { significant }\end{array}$ & $\begin{array}{c}\text { Extremely } \\
\text { significant }\end{array}$ & $\begin{array}{c}\text { Average } \\
\text { value }\end{array}$ \\
\hline $\begin{array}{l}\text { Inflexible for design } \\
\text { changes }\end{array}$ & $0 \%$ & $10 \%$ & $28 \%$ & $52 \%$ & $10 \%$ & 3.62 \\
\hline $\begin{array}{l}\text { Higher initial } \\
\text { construction cost }\end{array}$ & $2 \%$ & $19 \%$ & $19 \%$ & $58 \%$ & $2 \%$ & 3.39 \\
\hline $\begin{array}{l}\text { Lack of research } \\
\text { information }\end{array}$ & $0 \%$ & $12 \%$ & $40 \%$ & $40 \%$ & $8 \%$ & 3.44 \\
\hline Time consuming & $2 \%$ & $25 \%$ & $20 \%$ & $48 \%$ & $5 \%$ & 3.29 \\
\hline $\begin{array}{l}\text { Conventional } \\
\text { method }\end{array}$ & $8 \%$ & $10 \%$ & $40 \%$ & $39 \%$ & $3 \%$ & 3.19 \\
\hline Limited site space & $0 \%$ & $28 \%$ & $34 \%$ & $35 \%$ & $3 \%$ & 3.13 \\
\hline Leakage problems & $3 \%$ & $37 \%$ & $28 \%$ & $32 \%$ & $0 \%$ & 2.89 \\
\hline Lack of experience & $3 \%$ & $46 \%$ & $23 \%$ & $23 \%$ & $5 \%$ & 2.81 \\
\hline $\begin{array}{l}\text { Monotone in } \\
\text { aesthetics }\end{array}$ & $3 \%$ & $38 \%$ & $28 \%$ & $28 \%$ & $3 \%$ & 2.90 \\
\hline $\begin{array}{l}\text { No demand for } \\
\text { prefabrication }\end{array}$ & $0 \%$ & $52 \%$ & $35 \%$ & $8 \%$ & $5 \%$ & 2.66 \\
\hline
\end{tabular}


Table 5: Future development for prefabrication applications

\begin{tabular}{|l|c|c|c|c|c|c|}
\hline $\begin{array}{l}\text { Future } \\
\text { development }\end{array}$ & $\begin{array}{c}\text { Least } \\
\text { significant }\end{array}$ & $\begin{array}{c}\text { Fairly } \\
\text { significant }\end{array}$ & Significant & $\begin{array}{c}\text { Very } \\
\text { significant }\end{array}$ & $\begin{array}{c}\text { Extremely } \\
\text { significant }\end{array}$ & $\begin{array}{c}\text { Average } \\
\text { value }\end{array}$ \\
\hline $\begin{array}{l}\text { Relaxation } \\
\text { GFA }\end{array}$ & $9 \%$ & $13 \%$ & $34 \%$ & $34 \%$ & $9 \%$ & 3.22 \\
\hline $\begin{array}{l}\text { Adopting } \\
\text { prefabrication } \\
\text { to the future } \\
\text { projects }\end{array}$ & $0 \%$ & $19 \%$ & $28 \%$ & $53 \%$ & $0 \%$ & 3.34 \\
\hline $\begin{array}{l}\text { Construction } \\
\text { method }\end{array}$ & $0 \%$ & $6 \%$ & $25 \%$ & $59 \%$ & $9 \%$ & 3.72 \\
\hline $\begin{array}{l}\text { Environment } \\
\text { as the first } \\
\text { priority }\end{array}$ & $3 \%$ & $47 \%$ & $28 \%$ & $16 \%$ & $6 \%$ & 2.75 \\
\hline $\begin{array}{l}\text { Develop } \\
\text { techniques }\end{array}$ & $6 \%$ & $13 \%$ & $22 \%$ & $59 \%$ & $0 \%$ & 3.34 \\
\hline
\end{tabular}


Table 6: Respondents on the effective prefabrication general model

\begin{tabular}{|c|c|c|c|c|c|c|c|}
\hline \multirow[t]{2}{*}{$\begin{array}{l}\text { Building } \\
\text { elements }\end{array}$} & \multirow[t]{2}{*}{ Sub-elements } & \multirow[t]{2}{*}{ Conventional } & \multicolumn{2}{|c|}{ Semi-prefabrication } & \multicolumn{2}{|c|}{$\begin{array}{l}\text { Comprehensive } \\
\text { prefabrication }\end{array}$} & \multirow{2}{*}{$\begin{array}{c}\text { Volumetric } \\
\text { Modular } \\
\text { building }\end{array}$} \\
\hline & & & $\begin{array}{c}\text { System } \\
\text { formwork }\end{array}$ & Non-structural & Structural & Pre-finished & \\
\hline \multirow[t]{2}{*}{ Substructure } & Foundation & $100 \%$ & $0 \%$ & $0 \%$ & $0 \%$ & $0 \%$ & $0 \%$ \\
\hline & Basement & $96.3 \%$ & $3.7 \%$ & $0 \%$ & $0 \%$ & $0 \%$ & $0 \%$ \\
\hline \multirow{3}{*}{$\begin{array}{l}\text { Drainage and } \\
\text { underground } \\
\text { services }\end{array}$} & Manhole & $48.1 \%$ & $7.4 \%$ & $11.1 \%$ & $29.6 \%$ & $3.7 \%$ & $0.0 \%$ \\
\hline & Piling & $69.2 \%$ & $0.0 \%$ & $11.5 \%$ & $11.5 \%$ & $7.7 \%$ & $0.0 \%$ \\
\hline & $\begin{array}{l}\text { Plant and } \\
\text { equipment }\end{array}$ & $76.0 \%$ & $0.0 \%$ & $4.0 \%$ & $8.0 \%$ & $8.0 \%$ & $4.0 \%$ \\
\hline \multirow{6}{*}{$\begin{array}{c}\text { Structural } \\
\text { frame }\end{array}$} & Column & $48.1 \%$ & $37.0 \%$ & $0.0 \%$ & $11.1 \%$ & $3.7 \%$ & $0.0 \%$ \\
\hline & Beam & $48.1 \%$ & $37.0 \%$ & $3.7 \%$ & $7.4 \%$ & $3.7 \%$ & $0.0 \%$ \\
\hline & Bearing wall & $42.3 \%$ & $26.9 \%$ & $3.8 \%$ & $19.2 \%$ & $3.8 \%$ & $3.8 \%$ \\
\hline & Lift shaft & $46.4 \%$ & $28.6 \%$ & $7.1 \%$ & $7.1 \%$ & $7.1 \%$ & $3.6 \%$ \\
\hline & Stairs & $20.0 \%$ & $30.0 \%$ & $0.0 \%$ & $30.0 \%$ & $13.3 \%$ & $6.7 \%$ \\
\hline & Slab & $20.0 \%$ & $30.0 \%$ & $0.0 \%$ & $30.0 \%$ & $13.3 \%$ & $6.7 \%$ \\
\hline \multirow[t]{2}{*}{ External works } & External wall & $20.7 \%$ & $17.2 \%$ & $10.3 \%$ & $20.7 \%$ & $20.7 \%$ & $10.3 \%$ \\
\hline & Roof & $66.7 \%$ & $11.1 \%$ & $3.7 \%$ & $11.1 \%$ & $7.4 \%$ & $0.0 \%$ \\
\hline \multirow[t]{5}{*}{ Internal works } & Partition wall & $16.7 \%$ & $10.0 \%$ & $20.0 \%$ & $16.7 \%$ & $23.3 \%$ & $13.3 \%$ \\
\hline & Plastering & $48.3 \%$ & $3.4 \%$ & $6.9 \%$ & $6.9 \%$ & $24.1 \%$ & $10.3 \%$ \\
\hline & Tiling & $48.4 \%$ & $3.2 \%$ & $3.2 \%$ & $9.7 \%$ & $22.6 \%$ & $12.9 \%$ \\
\hline & Washroom & $43.3 \%$ & $0.0 \%$ & $10.0 \%$ & $10.0 \%$ & $20.0 \%$ & $16.7 \%$ \\
\hline & Kitchen & $40.7 \%$ & $0.0 \%$ & $14.8 \%$ & $7.4 \%$ & $22.2 \%$ & $14.8 \%$ \\
\hline \multirow[t]{4}{*}{$\begin{array}{l}\text { Building } \\
\text { services }\end{array}$} & $\begin{array}{l}\text { Distribution } \\
\text { ductwork }\end{array}$ & $59.3 \%$ & $0.0 \%$ & $22.2 \%$ & $7.4 \%$ & $11.1 \%$ & $0.0 \%$ \\
\hline & Plant room & $76.9 \%$ & $0.0 \%$ & $11.5 \%$ & $3.8 \%$ & $0.0 \%$ & $7.7 \%$ \\
\hline & Lift & $67.9 \%$ & $3.6 \%$ & $7.1 \%$ & $7.1 \%$ & $10.7 \%$ & $3.6 \%$ \\
\hline & Escalator & $63.0 \%$ & $3.7 \%$ & $7.4 \%$ & $11.1 \%$ & $7.4 \%$ & $7.4 \%$ \\
\hline
\end{tabular}


Table 7: Respondents on the effective prefabrication public housing project model

\begin{tabular}{|c|c|c|c|c|c|c|c|}
\hline \multirow[t]{2}{*}{ Trade } & \multirow[t]{2}{*}{ Elements } & \multirow[t]{2}{*}{ Conventional } & \multicolumn{2}{|c|}{ Semi-prefabrication } & \multicolumn{2}{|c|}{$\begin{array}{l}\text { Comprehensive } \\
\text { prefabrication }\end{array}$} & \multirow{2}{*}{$\begin{array}{c}\text { Volumetric } \\
\text { Modular } \\
\text { building }\end{array}$} \\
\hline & & & $\begin{array}{c}\text { System } \\
\text { formwork }\end{array}$ & Non-structural & Structural & Pre-finished & \\
\hline \multirow[t]{2}{*}{ Substructure } & Foundation & $100 \%$ & $0 \%$ & $0 \%$ & $0 \%$ & $0 \%$ & $0 \%$ \\
\hline & Basement & $100 \%$ & $0 \%$ & $0 \%$ & $0 \%$ & $0 \%$ & $0 \%$ \\
\hline \multirow{3}{*}{$\begin{array}{c}\text { Drainage and } \\
\text { underground } \\
\text { services }\end{array}$} & Manhole & $66.7 \%$ & $0.0 \%$ & $0.0 \%$ & $33.3 \%$ & $0.0 \%$ & $66.7 \%$ \\
\hline & Piling & $66.7 \%$ & $0.0 \%$ & $0.0 \%$ & $33.3 \%$ & $0.0 \%$ & $66.7 \%$ \\
\hline & $\begin{array}{l}\text { Plant and } \\
\text { equipment }\end{array}$ & $66.7 \%$ & $0.0 \%$ & $0.0 \%$ & $0.0 \%$ & $33.3 \%$ & $66.7 \%$ \\
\hline \multirow[t]{6}{*}{ Structural frame } & Column & $33.3 \%$ & $33.3 \%$ & $0.0 \%$ & $0.0 \%$ & $33.3 \%$ & $33.3 \%$ \\
\hline & Beam & $50.0 \%$ & $0.0 \%$ & $0.0 \%$ & $25.0 \%$ & $25.0 \%$ & $50.0 \%$ \\
\hline & Bearing wall & $33.3 \%$ & $33.3 \%$ & $0.0 \%$ & $0.0 \%$ & $33.3 \%$ & $33.3 \%$ \\
\hline & Lift shaft & $50.0 \%$ & $0.0 \%$ & $0.0 \%$ & $0.0 \%$ & $50.0 \%$ & $50.0 \%$ \\
\hline & Stairs & $0.0 \%$ & $0.0 \%$ & $0.0 \%$ & $0.0 \%$ & $50.0 \%$ & $0.0 \%$ \\
\hline & Slab & $0.0 \%$ & $0.0 \%$ & $0.0 \%$ & $33.3 \%$ & $33.3 \%$ & $0.0 \%$ \\
\hline \multirow[t]{2}{*}{ External works } & External wall & $0.0 \%$ & $0.0 \%$ & $0.0 \%$ & $50.0 \%$ & $50.0 \%$ & $0.0 \%$ \\
\hline & Roof & $66.7 \%$ & $0.0 \%$ & $0.0 \%$ & $0.0 \%$ & $33.3 \%$ & $66.7 \%$ \\
\hline \multirow[t]{5}{*}{ Internal works } & Partition wall & $0.0 \%$ & $0.0 \%$ & $0.0 \%$ & $50.0 \%$ & $50.0 \%$ & $0.0 \%$ \\
\hline & Plastering & $25.0 \%$ & $0.0 \%$ & $0.0 \%$ & $25.0 \%$ & $50.0 \%$ & $25.0 \%$ \\
\hline & Tiling & $25.0 \%$ & $0.0 \%$ & $0.0 \%$ & $25.0 \%$ & $25.0 \%$ & $25.0 \%$ \\
\hline & Washroom & $25.0 \%$ & $0.0 \%$ & $0.0 \%$ & $25.0 \%$ & $25.0 \%$ & $25.0 \%$ \\
\hline & Kitchen & $25.0 \%$ & $0.0 \%$ & $0.0 \%$ & $25.0 \%$ & $25.0 \%$ & $25.0 \%$ \\
\hline \multirow[t]{4}{*}{$\begin{array}{l}\text { Building } \\
\text { services }\end{array}$} & $\begin{array}{c}\text { Distribution } \\
\text { ductwork }\end{array}$ & $66.7 \%$ & $0.0 \%$ & $0.0 \%$ & $0.0 \%$ & $33.3 \%$ & $66.7 \%$ \\
\hline & Plant room & $66.7 \%$ & $0.0 \%$ & $0.0 \%$ & $0.0 \%$ & $0.0 \%$ & $66.7 \%$ \\
\hline & Lift & $66.7 \%$ & $0.0 \%$ & $0.0 \%$ & $0.0 \%$ & $33.3 \%$ & $66.7 \%$ \\
\hline & Escalator & $66.7 \%$ & $0.0 \%$ & $0.0 \%$ & $0.0 \%$ & $0.0 \%$ & $66.7 \%$ \\
\hline
\end{tabular}


Table 8: Respondents on the effective prefabrication private residential project model

\begin{tabular}{|c|c|c|c|c|c|c|c|}
\hline \multirow[t]{2}{*}{ Trade } & \multirow[t]{2}{*}{ Elements } & \multirow[t]{2}{*}{ Conventional } & \multicolumn{2}{|c|}{ Semi-prefabrication } & \multicolumn{2}{|c|}{$\begin{array}{l}\text { Comprehensive } \\
\text { prefabrication }\end{array}$} & \multirow{2}{*}{$\begin{array}{c}\text { Volumetric } \\
\text { Modular } \\
\text { building }\end{array}$} \\
\hline & & & $\begin{array}{l}\text { System } \\
\text { formwork }\end{array}$ & Non-structural & Structural & Pre-finished & \\
\hline \multirow[t]{2}{*}{ Substructure } & Foundation & $100.0 \%$ & $0.0 \%$ & $0.0 \%$ & $0.0 \%$ & $0.0 \%$ & $100.0 \%$ \\
\hline & Basement & $100.0 \%$ & $0.0 \%$ & $0.0 \%$ & $0.0 \%$ & $0.0 \%$ & $100.0 \%$ \\
\hline \multirow{3}{*}{$\begin{array}{l}\text { Drainage and } \\
\text { underground } \\
\text { services }\end{array}$} & Manhole & $42.9 \%$ & $0.0 \%$ & $28.6 \%$ & $28.6 \%$ & $0.0 \%$ & $42.9 \%$ \\
\hline & Piling & $71.4 \%$ & $0.0 \%$ & $28.6 \%$ & $0.0 \%$ & $0.0 \%$ & $71.4 \%$ \\
\hline & $\begin{array}{l}\text { Plant and } \\
\text { equipment }\end{array}$ & $71.4 \%$ & $0.0 \%$ & $14.3 \%$ & $14.3 \%$ & $0.0 \%$ & $71.4 \%$ \\
\hline \multirow{6}{*}{$\begin{array}{l}\text { Structural } \\
\text { frame }\end{array}$} & Column & $71.4 \%$ & $14.3 \%$ & $0.0 \%$ & $14.3 \%$ & $0.0 \%$ & $71.4 \%$ \\
\hline & Beam & $57.1 \%$ & $28.6 \%$ & $0.0 \%$ & $14.3 \%$ & $0.0 \%$ & $57.1 \%$ \\
\hline & Bearing wall & $57.1 \%$ & $14.3 \%$ & $0.0 \%$ & $28.6 \%$ & $0.0 \%$ & $57.1 \%$ \\
\hline & Lift shaft & $71.4 \%$ & $14.3 \%$ & $0.0 \%$ & $14.3 \%$ & $0.0 \%$ & $71.4 \%$ \\
\hline & Stairs & $12.5 \%$ & $12.5 \%$ & $0.0 \%$ & $62.5 \%$ & $12.5 \%$ & $12.5 \%$ \\
\hline & Slab & $12.5 \%$ & $12.5 \%$ & $0.0 \%$ & $62.5 \%$ & $12.5 \%$ & $12.5 \%$ \\
\hline \multirow[t]{2}{*}{ External works } & External wall & $11.1 \%$ & $0.0 \%$ & $11.1 \%$ & $33.3 \%$ & $44.4 \%$ & $11.1 \%$ \\
\hline & Roof & $57.1 \%$ & $0.0 \%$ & $14.3 \%$ & $28.6 \%$ & $0.0 \%$ & $57.1 \%$ \\
\hline \multirow[t]{5}{*}{ Internal works } & Partition wall & $0.0 \%$ & $11.1 \%$ & $22.2 \%$ & $22.2 \%$ & $44.4 \%$ & $0.0 \%$ \\
\hline & Plastering & $25.0 \%$ & $12.5 \%$ & $12.5 \%$ & $12.5 \%$ & $37.5 \%$ & $25.0 \%$ \\
\hline & Tiling & $40.0 \%$ & $10.0 \%$ & $0.0 \%$ & $20.0 \%$ & $30.0 \%$ & $40.0 \%$ \\
\hline & Washroom & $22.2 \%$ & $0.0 \%$ & $22.2 \%$ & $22.2 \%$ & $33.3 \%$ & $22.2 \%$ \\
\hline & Kitchen & $33.3 \%$ & $0.0 \%$ & $22.2 \%$ & $11.1 \%$ & $33.3 \%$ & $33.3 \%$ \\
\hline \multirow[t]{4}{*}{$\begin{array}{l}\text { Building } \\
\text { services }\end{array}$} & $\begin{array}{l}\text { Distribution } \\
\text { ductwork }\end{array}$ & $42.9 \%$ & $0.0 \%$ & $42.9 \%$ & $14.3 \%$ & $0.0 \%$ & $42.9 \%$ \\
\hline & Plant room & $71.4 \%$ & $0.0 \%$ & $28.6 \%$ & $0.0 \%$ & $0.0 \%$ & $71.4 \%$ \\
\hline & Lift & $71.4 \%$ & $0.0 \%$ & $28.6 \%$ & $0.0 \%$ & $0.0 \%$ & $71.4 \%$ \\
\hline & Escalator & $71.4 \%$ & $0.0 \%$ & $28.6 \%$ & $0.0 \%$ & $0.0 \%$ & $71.4 \%$ \\
\hline
\end{tabular}


Table 9: Respondents on the effective prefabrication commercial project model

\begin{tabular}{|c|c|c|c|c|c|c|c|}
\hline \multirow[t]{2}{*}{ Trade } & \multirow[t]{2}{*}{ Elements } & \multirow[t]{2}{*}{ Conventional } & \multicolumn{2}{|c|}{ Semi-prefabrication } & \multicolumn{2}{|c|}{$\begin{array}{l}\text { Comprehensive } \\
\text { prefabrication }\end{array}$} & \multirow{2}{*}{$\begin{array}{c}\text { Volumetric } \\
\text { Modular } \\
\text { building }\end{array}$} \\
\hline & & & $\begin{array}{l}\text { System } \\
\text { formwork }\end{array}$ & Non-structural & Structural & Pre-finished & \\
\hline \multirow[t]{2}{*}{ Substructure } & Foundation & $90.9 \%$ & $9.1 \%$ & $0.0 \%$ & $0.0 \%$ & $0.0 \%$ & $90.9 \%$ \\
\hline & Basement & $76.9 \%$ & $23.1 \%$ & $0.0 \%$ & $0.0 \%$ & $0.0 \%$ & $76.9 \%$ \\
\hline \multirow{3}{*}{$\begin{array}{c}\text { Drainage and } \\
\text { underground } \\
\text { services }\end{array}$} & Manhole & $25.0 \%$ & $0.0 \%$ & $0.0 \%$ & $75.0 \%$ & $0.0 \%$ & $25.0 \%$ \\
\hline & Piling & $25.0 \%$ & $0.0 \%$ & $25.0 \%$ & $25.0 \%$ & $25.0 \%$ & $25.0 \%$ \\
\hline & $\begin{array}{l}\text { Plant and } \\
\text { equipment }\end{array}$ & $50.0 \%$ & $0.0 \%$ & $0.0 \%$ & $0.0 \%$ & $25.0 \%$ & $50.0 \%$ \\
\hline \multirow[t]{6}{*}{ Structural frame } & Column & $0.0 \%$ & $75.0 \%$ & $0.0 \%$ & $25.0 \%$ & $0.0 \%$ & $0.0 \%$ \\
\hline & Beam & $0.0 \%$ & $75.0 \%$ & $0.0 \%$ & $25.0 \%$ & $0.0 \%$ & $0.0 \%$ \\
\hline & Bearing wall & $25.0 \%$ & $50.0 \%$ & $0.0 \%$ & $25.0 \%$ & $0.0 \%$ & $25.0 \%$ \\
\hline & Lift shaft & $25.0 \%$ & $50.0 \%$ & $0.0 \%$ & $25.0 \%$ & $0.0 \%$ & $25.0 \%$ \\
\hline & Stairs & $0.0 \%$ & $60.0 \%$ & $0.0 \%$ & $20.0 \%$ & $20.0 \%$ & $0.0 \%$ \\
\hline & Slab & $0.0 \%$ & $60.0 \%$ & $0.0 \%$ & $20.0 \%$ & $20.0 \%$ & $0.0 \%$ \\
\hline \multirow[t]{2}{*}{ External works } & External wall & $25.0 \%$ & $25.0 \%$ & $50.0 \%$ & $0.0 \%$ & $0.0 \%$ & $25.0 \%$ \\
\hline & Roof & $40.0 \%$ & $20.0 \%$ & $0.0 \%$ & $20.0 \%$ & $20.0 \%$ & $40.0 \%$ \\
\hline \multirow[t]{5}{*}{ Internal works } & Partition wall & $50.0 \%$ & $0.0 \%$ & $25.0 \%$ & $0.0 \%$ & $0.0 \%$ & $50.0 \%$ \\
\hline & Plastering & $50.0 \%$ & $0.0 \%$ & $0.0 \%$ & $0.0 \%$ & $25.0 \%$ & $50.0 \%$ \\
\hline & Tiling & $50.0 \%$ & $0.0 \%$ & $0.0 \%$ & $0.0 \%$ & $25.0 \%$ & $50.0 \%$ \\
\hline & Washroom & $50.0 \%$ & $0.0 \%$ & $0.0 \%$ & $0.0 \%$ & $0.0 \%$ & $50.0 \%$ \\
\hline & Kitchen & $0.0 \%$ & $0.0 \%$ & $50.0 \%$ & $0.0 \%$ & $0.0 \%$ & $0.0 \%$ \\
\hline \multirow[t]{4}{*}{$\begin{array}{l}\text { Building } \\
\text { services }\end{array}$} & $\begin{array}{c}\text { Distribution } \\
\text { ductwork }\end{array}$ & $20.0 \%$ & $0.0 \%$ & $40.0 \%$ & $20.0 \%$ & $20.0 \%$ & $20.0 \%$ \\
\hline & Plant room & $25.0 \%$ & $0.0 \%$ & $25.0 \%$ & $25.0 \%$ & $0.0 \%$ & $25.0 \%$ \\
\hline & Lift & $16.7 \%$ & $16.7 \%$ & $0.0 \%$ & $33.3 \%$ & $33.3 \%$ & $16.7 \%$ \\
\hline & Escalator & $16.7 \%$ & $16.7 \%$ & $0.0 \%$ & $33.3 \%$ & $33.3 \%$ & $16.7 \%$ \\
\hline
\end{tabular}


Table 10: Details of the interviewed construction projects

\begin{tabular}{|c|c|c|c|}
\hline Respondent & Private / public & Type of project & Method of construction \\
\hline 1 & Private & Residential & Conventional \\
\hline 2 & Private & Residential & Conventional \\
\hline 3 & Private & Residential & Conventional \\
\hline 4 & Private & Residential & Conventional \\
\hline 5 & Private & Commercial & Conventional \\
\hline 6 & Private & Commercial & Conventional \\
\hline 7 & Private & Industrial & Conventional \\
\hline 8 & Private & Industrial & Conventional \\
\hline 9 & Public & Industrial & Conventional \\
\hline 10 & Private & Office & Conventional \\
\hline 11 & Private & Hotel & Conventional \\
\hline 12 & Private & Hotel & Conventional \\
\hline 13 & Private & School & Conventional \\
\hline 14 & Public & School & Conventional \\
\hline 15 & Private & Residential & Semi-prefabrication \\
\hline 16 & Private & Residential & Semi-prefabrication \\
\hline 17 & Private & Residential & Semi-prefabrication \\
\hline 18 & Private & Residential & Semi-prefabrication \\
\hline 19 & Private & Residential & Semi-prefabrication \\
\hline 20 & Public & Residential & Semi-prefabrication \\
\hline 21 & Public & Residential & Semi-prefabrication \\
\hline 22 & Public & Residential & Semi-prefabrication \\
\hline 23 & Public & Residential & Semi-prefabrication \\
\hline 24 & Public & Residential & Semi-prefabrication \\
\hline 25 & Public & Residential & Semi-prefabrication \\
\hline 26 & Public & Residential & Semi-prefabrication \\
\hline 27 & Private & Commercial & Semi-prefabrication \\
\hline 28 & Public & Commercial & Semi-prefabrication \\
\hline 29 & Public & Office & Semi-prefabrication \\
\hline 30 & Public & Office & Semi-prefabrication \\
\hline
\end{tabular}


Table 11: Measured conventional construction projects in Hong Kong

\begin{tabular}{|l|c|c|}
\hline & Private housing & Public housing \\
\hline Residential & $4(28.7 \%)$ & $0(0 \%)$ \\
\hline Commercial & $2(14.3 \%)$ & $0(0 \%)$ \\
\hline Industrial & $2(14.3 \%)$ & $1(7.1 \%)$ \\
\hline Office & $1(7.1 \%)$ & $0(0 \%)$ \\
\hline Hotel & $2(14.3 \%)$ & $0(0 \%)$ \\
\hline School & $1(7.1 \%)$ & $1(7.1 \%)$ \\
\hline
\end{tabular}


Table 12: Measured semi-prefabrication construction projects in Hong Kong

\begin{tabular}{|l|c|c|}
\hline & Private housing & Public housing \\
\hline Residential & $5(31 \%)$ & $7(44.5 \%)$ \\
\hline Commercial & $1(6 \%)$ & $1(6 \%)$ \\
\hline Office & $0(0 \%)$ & $2(12.5 \%)$ \\
\hline
\end{tabular}


Table 13: Wastage between cast-in-situ and prefabrication

\begin{tabular}{|l|c|c|c|}
\hline \multirow{2}{*}{ Trades } & \multicolumn{2}{|c|}{ Average wastage level (in \%) } & \multirow{2}{*}{$\begin{array}{c}\text { Percentage of waste } \\
\text { reduction [C=(A-B)/A] }\end{array}$} \\
\cline { 2 - 3 } & Conventional (A) & Prefabrication (B) & $90 \%$ \\
\hline Concreting & 20 & 2 & $92 \%$ \\
\hline Rebar fixing & 25 & 2 & - \\
\hline Bricklaying & 15 & - & - \\
\hline Drywall & - & 5 & $100 \%$ \\
\hline Plastering & 23 & 0 & - \\
\hline Screeding & 25 & - & $74 \%$ \\
\hline Tiling & 27 & 7 & \\
\hline
\end{tabular}


Table 14: Percentage wastage of materials for various trades for private and public housing

projects [21]

\begin{tabular}{|l|l|c|c|}
\hline Trade & Material & $\begin{array}{c}\text { Percentage wastage } \\
\text { in private housing }\end{array}$ & $\begin{array}{c}\text { Percentage wastage } \\
\text { in public housing }\end{array}$ \\
\hline Concreting & Concrete & $4-5 \%$ & $3-5 \%$ \\
\hline Reinforcement & Steel bars & $1-8 \%$ & $3-5 \%$ \\
\hline Drywall & Drywall & $6-10 \%$ & $5 \%$ \\
\hline Plastering & Plastering & $4-20 \%$ & $2 \%$ \\
\hline Screeding & Screeding & $4-20 \%$ & $7 \%$ \\
\hline Tile & Tile & $4-10 \%$ & $6-8 \%$ \\
\hline Formwork & Timber broad & $15 \%$ & $5 \%$ \\
\hline Masonry & Brick and block & $4-8 \%$ & $6 \%$ \\
\hline
\end{tabular}


Table 15: Project Details

\begin{tabular}{|c|c|c|c|c|c|c|c|c|c|}
\hline Materials & $\begin{array}{c}\text { Quantity } \\
\text { [A] }\end{array}$ & $\begin{array}{c}\text { Unit Price } \\
\text { (HK\$) } \\
\text { [B] }\end{array}$ & $\begin{array}{c}\text { Waste } \\
\text { Level } \\
\text { [C] }\end{array}$ & $\begin{array}{c}\text { Wastage } \\
\text { Reduction } \\
\text { Level } \\
\text { [D] }\end{array}$ & $\begin{array}{c}\text { Original } \\
\text { Quantity of } \\
\text { Waste } \\
\text { [E=AxC] }\end{array}$ & $\begin{array}{c}\text { New } \\
\text { Quanitty of } \\
\text { Waste } \\
{[\mathrm{F}=\mathrm{ExD}]}\end{array}$ & $\begin{array}{l}\text { Original Amount } \\
\text { Used for Wastege } \\
\text { (HK\$) [G=ExB] }\end{array}$ & $\begin{array}{c}\text { New Amount } \\
\text { Used for } \\
\text { Wastege (HK\$) } \\
\text { [H=FxB] }\end{array}$ & $\begin{array}{l}\text { Amount Saved on } \\
\text { Wastage [I=G-H] }\end{array}$ \\
\hline Concrete $\left(\mathrm{m}^{3}\right)$ & 50,000 & 450 & $20 \%$ & $90 \%$ & 10,000 & 1,000 & $\$ 4,500,000$ & $\$ 450,000$ & $\$ 4,050,000$ \\
\hline Reinforcement (ton) & 6,500 & 1000 & $20 \%$ & $92 \%$ & 1,300 & 104 & $\$ 1,300,000$ & $\$ 104,000$ & $\$ 1,196,000$ \\
\hline Plastering (m2) & 250,000 & 250 & $10 \%$ & $100 \%$ & 25,000 & 0 & $\$ 6,250,000$ & $\$ 0$ & $\$ 6,250,000$ \\
\hline Tiling (m2) & 400,000 & 300 & $10 \%$ & $74 \%$ & 40,000 & 10,400 & $\$ 12,000,000$ & $\$ 3,120,000$ & $\$ 8,880,000$ \\
\hline & & & & & & Total & $\$ 24,050,000$ & $\$ 3,674,000$ & $\$ 20,376,000(=84.7 \%)$ \\
\hline
\end{tabular}




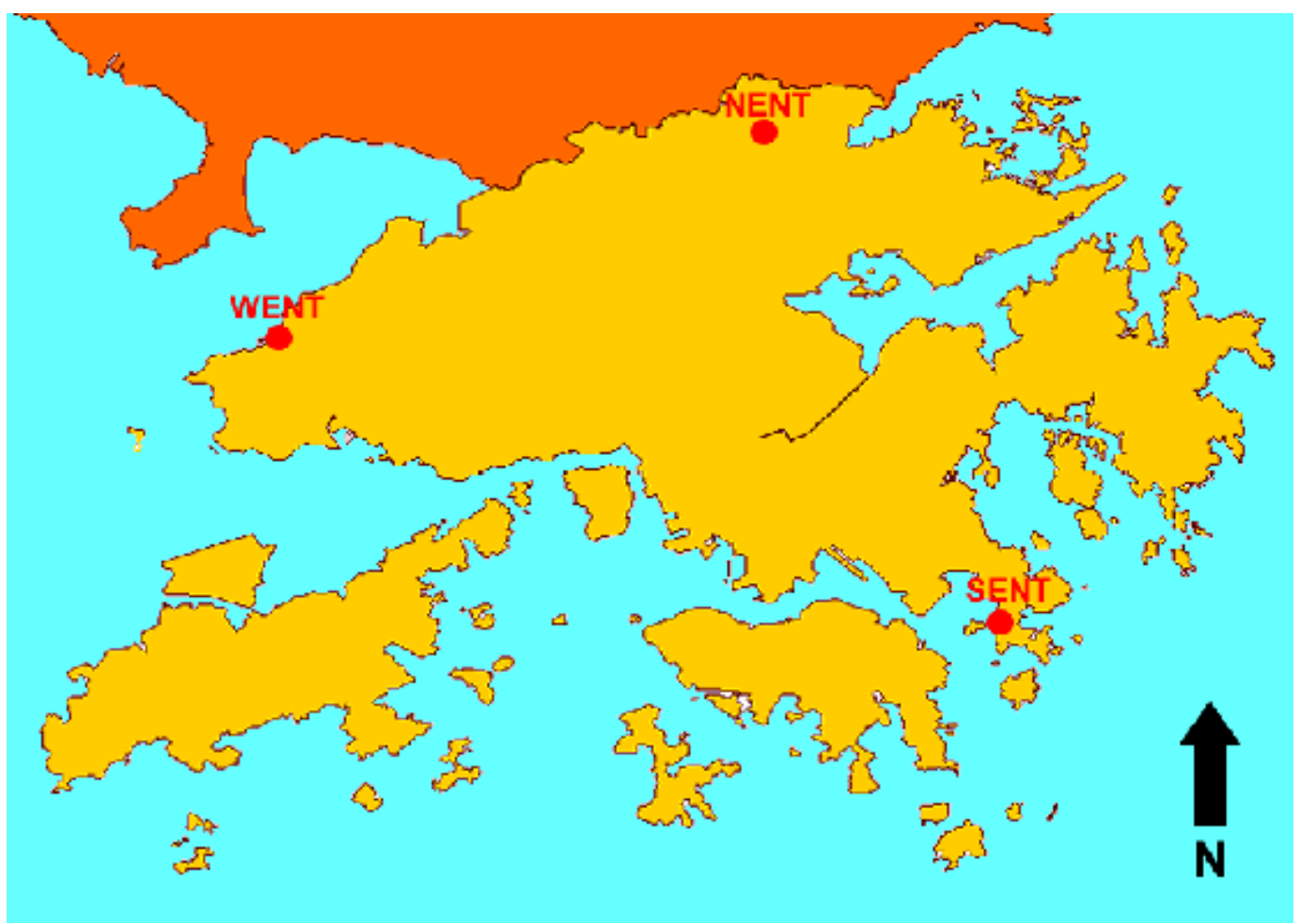

Figure 1: Location of existing strategic landfills [13] 


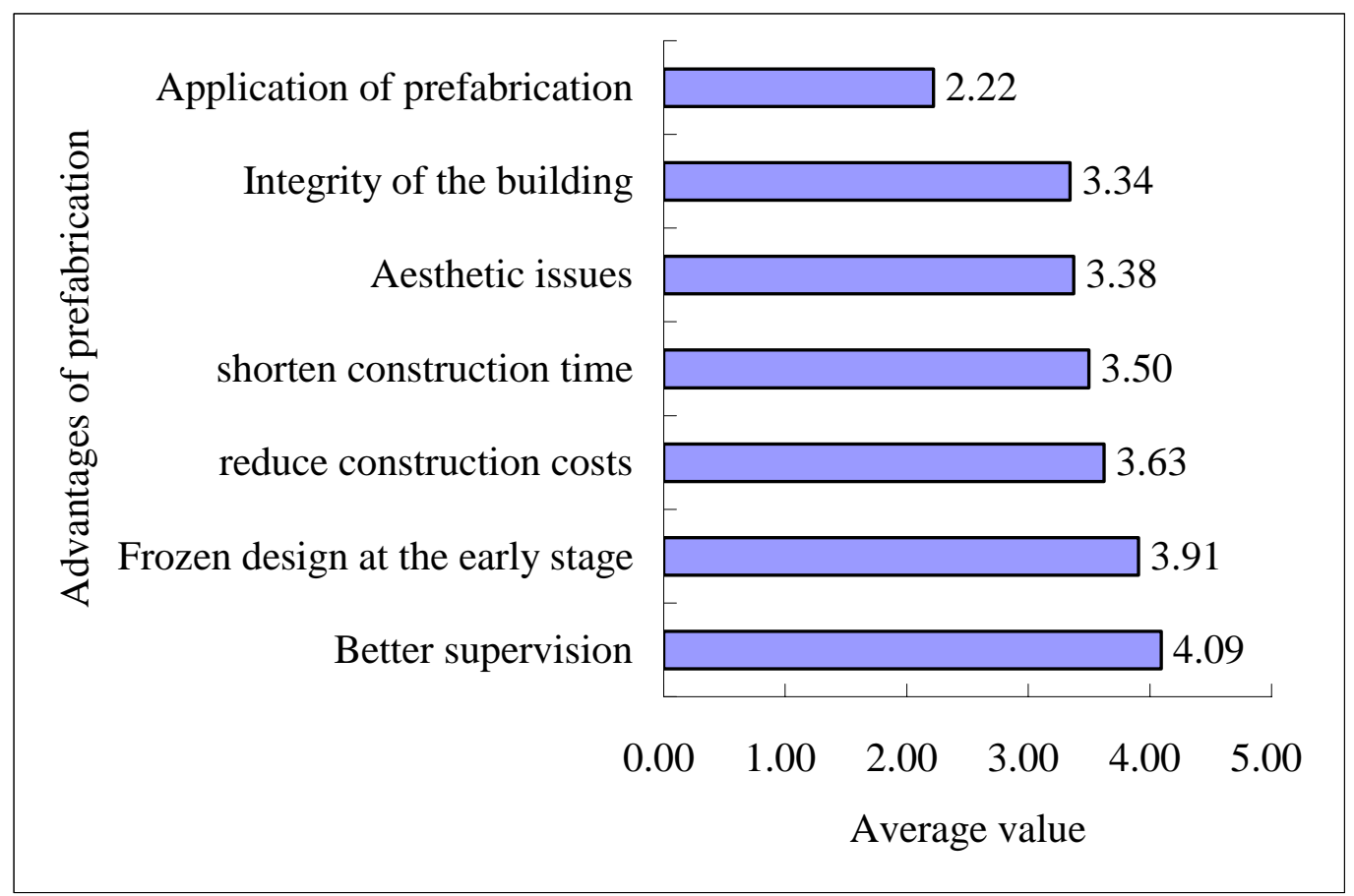

Figure 2: Advantages of applying prefabrication 


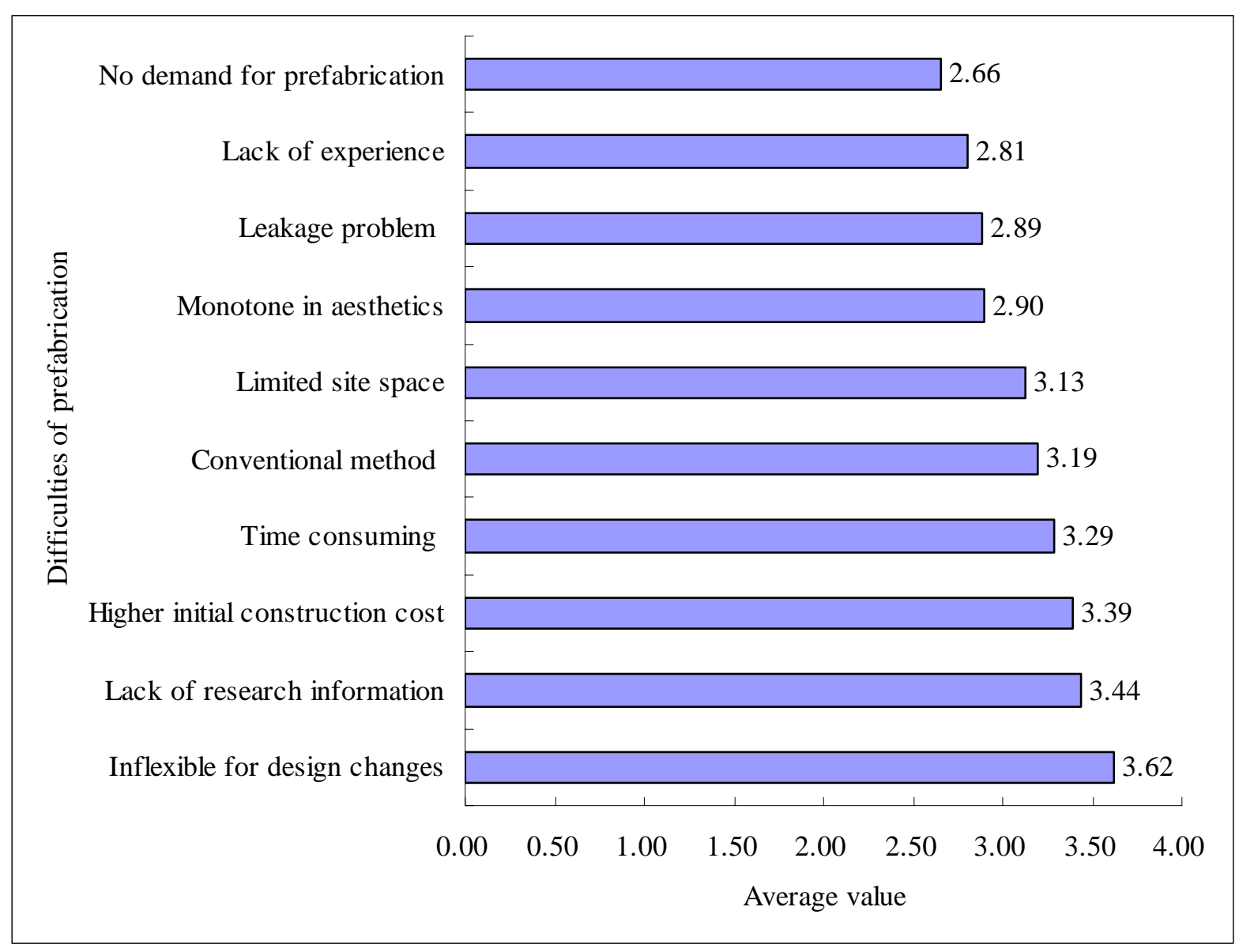

Figure 3: Hindrances on applying prefabrication 


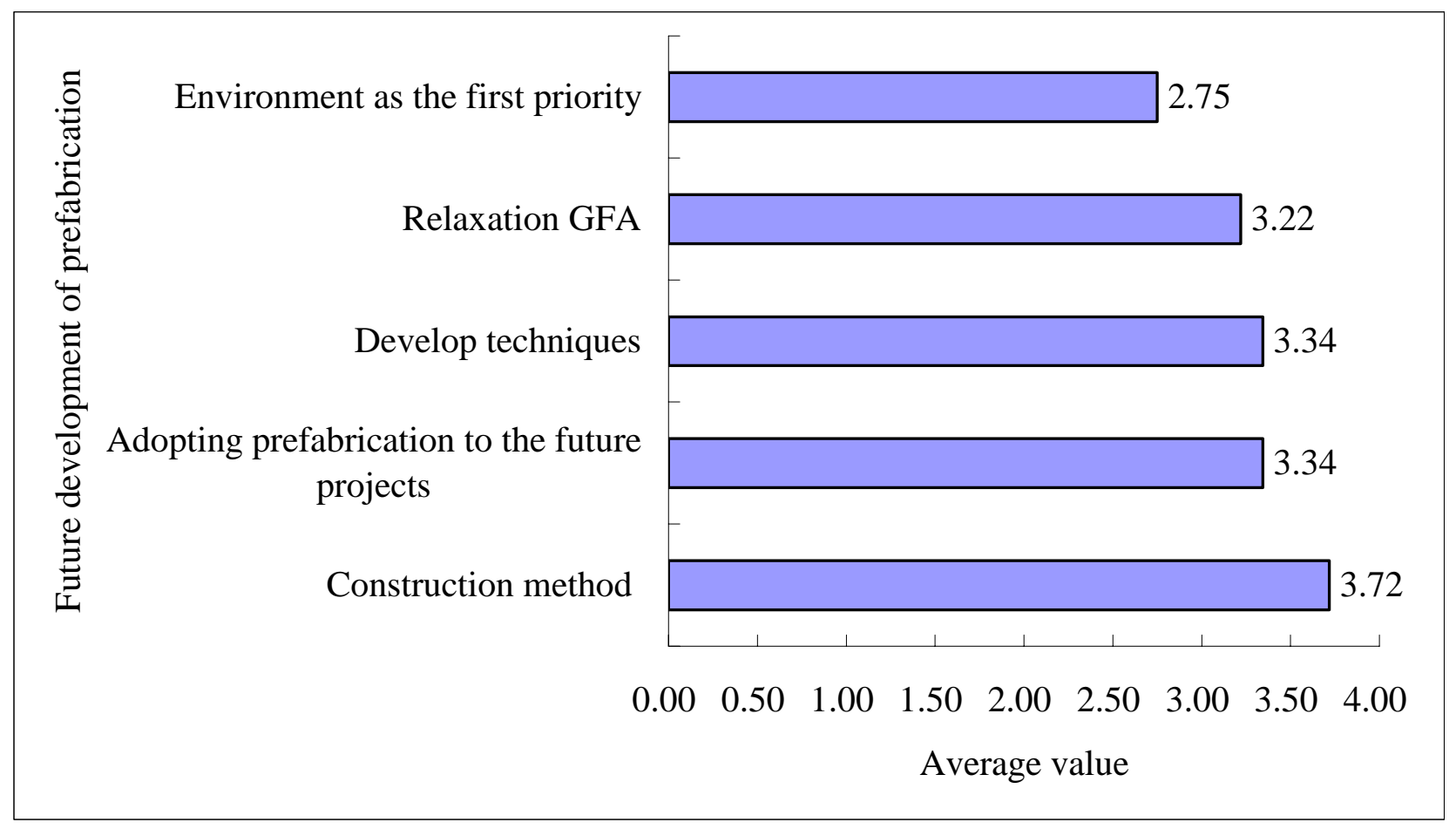

Figure 4: Future development for prefabrication applications 